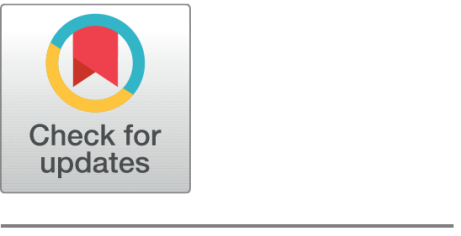

OPEN ACCESS

Received: 25.09.2020

Accepted: 12.01 .2021

Published: 02.02.2021

Citation: Kusuma KN, Lakshmi Ram Prasath H (2021) Application of Feature Based Principal Component Analysis (FPCA) technique on Landsat8 OLI multispectral data to map Kimberlite pipes. Indian Journal of Science and Technology 14(4): 361-372. https://doi.org/ 10.17485/IJST/v14i4.1741

* Corresponding author.

Tel: +91-413-2654-918

kusuma.kn@gmail.com

Funding: None

Competing Interests: None

Copyright: (c) 2021 Kusuma \& Lakshmi Ram Prasath. This is an open access article distributed under the terms of the Creative Commons Attribution License, which permits unrestricted use, distribution, and reproduction in any medium, provided the original author and source are credited.

Published By Indian Society for Education and Environment (iSee)

ISSN

Print: 0974-6846

Electronic: 0974-5645

\section{Application of Feature Based Principal Component Analysis (FPCA) technique on Landsat8 OLI multispectral data to map Kimberlite pipes}

\author{
K N Kusuma ${ }^{1 *}$, H Lakshmi Ram Prasath ${ }^{2}$ \\ 1 Assistant Professor, Department of Earth Sciences, Pondicherry University, Puducherry, \\ 605014, India. Tel.: +91-413-2654-918 \\ 2 Department of Earth Sciences, Pondicherry University, Puducherry, 605014, India
}

\section{Abstract}

Objectives: To map the kimberlite pipes emplaced in parts of Anantpur District, India using Landsat-8 OLI multispectral data. Kimberlite are considered as the primary host of natural diamond. Kimberlite pipes have very limited exposure and are altered, therefore the indirect surface indicators associated with kimberlite such as ferric iron bearing minerals (hematite, goethite), hydroxyl (clay) and carbonate (calcrete) minerals, were mapped to trace kimberlite pipe. Methods: Feature based Principal Component Analysis (FPCA) was applied over the OLI bands 2, 4, 5 and 6, and 2, 5, 6 and 7 to generate ferric iron ( $F$ image) and hydroxyl/carbonate image ( $\mathrm{H} / \mathrm{C}$ images). The color composite was generated by assigning RGB colours to $F, H / C$ and $F+H / C$ images. Findings: When matched with the pre-explored kimberlite pipe locations, it was observed that the kimberlitic pipes display different colours in the above colour composite. Hence, the Isodata clustering was carried out to segregate the classes, which resulted in 12 unique classes. Of these, the kimberlite pipes fall in 4 classes. However, due to the moderate resolution of OLI, false positive areas were also noted. Further the target area was found to be reduced by incorporating the structural control (lineament) over the emplacement of Kimberlite pipes. Novelty: The present work highlights the usefulness of the moderate resolution multispectral image in mapping the Kimberlite pipes in semiarid region, in absence of a hyperspectral sensor.

Keywords: Kimberlite; Landsat8 OLl; feature based Principal Component Analysis (FPCA); Lineaments; Dharwar Craton

\section{Introduction}

Kimberlites are rare igneous rocks. They are considered to be geochemists probe to the earth's mantle due to presence of mantle xenocrysts carried by the kimberlite magma originating in the deep mantle. Presence of natural diamond in some of the kimberlite pipes makes them economically important ${ }^{(1-3)}$. These unique ultrabasic and ultrapotassic volcanic rocks, essentially having mantle xenolith showing porphyritic 
texture, mainly composed of olivine were first noted in the Kimberley region of South Africa in $1869^{(1-4)}$. Highly volatile fluid rich Kimberlitic magma originating at deep mantle, ascend rapidly (order of $400 \mathrm{~m} / \mathrm{s}$ ) and get emplaced in carrot shaped pipes or diatremes $^{(3-6)}$. Most of kimberlite pipes are found to be emplaced on the stable part of the ancient craton having age older than $2.4 \mathrm{Ga}$ except a few pipes that are emplaced on the younger accreted belts of cratonized region of around $1100 \mathrm{Ma}{ }^{(5,6)}$. The pipes found in the cratonic part are more likely to be diamondiferous, compared to those emplaced in the younger accreted parts ${ }^{(6)}$. World over studies have revealed that the Kimberlite pipe are found to be emplaced in vicinity of regional weak zones formed due to extensional tectonics and at intersection of regional compressional structures with regional faults or lineaments ${ }^{(7-9)}$. The pipes are circular or elliptical in outline with a dimension ranging from $100 \mathrm{~m}^{2}$ to $1000-2000 \mathrm{~m}^{2}$. Kimberlite pipes are usually found to be emplaced as clusters, with each cluster having more than one pipe. Kimberlite field is defined by grouping of several cluster of pipes together occurring in an area ${ }^{(10,11)}$.

As the kimberlite is the primary host rock of the diamond that have high economic values, locating the kimberlite pipe gains the prime importance while carrying out exploration for diamond. The challenges faced during exploration are mainly due to (i) small spatial dimension of the pipe (ii) high degree of weathering in the humid tropical climates and (iii) mantling of the pipes by the alluvium in the low-lying areas or development of calcrete over the pipes. Technique employed in exploring kimberlite pipe include photo-geological interpretation of aerial photo or satellite imageries, ${ }^{(8)}$ multispectral, hyperspectral remote sensing and GIS ${ }^{(12-18)}$; geochemical prospecting techniques such as analysis of soil sample, Kimberlite indicator minerals (KIMs) from stream sediment samples ${ }^{(19,20)}$ and calcrete geochemistry ${ }^{(21)}$; and geophysical methods including electromagnetic ${ }^{(22)}$, aeromagnetic, ground magnetic studies and gravity method ${ }^{(23,24)}$.

Photo-geological interpretation of aerial photo or satellite imageries are used for mapping the structural features found in association with kimberlite such as regional lineaments, dyke intrusion and geomorphology ${ }^{(8,9,12,17,18)}$. In recent years, spectral based remote sensing has also been widely used in exploration of mineral deposits based on the spectral characteristic of the path finder minerals ${ }^{(25-27)}$. Even though hyperspectral data is preferred for mineral exploration owing to their higher spectral resolution, their availability is limited. Hence, the broad band multispectral images such as Landsat TM, ETM+ and ASTER are used for exploring the mineral deposits ${ }^{(27-34)}$, with use of Image processing techniques such as band ratio, Principle Component Analysis (PCA), FPSCA or Crosta technique ${ }^{(28,29)}$ etc.

Principal component analysis (PCA) is a common image processing method applied over multispectral images for mapping alteration zones in metallogenic provinces ${ }^{(27-34)}$. The Feature Oriented Principal Components selection (FPCS), also known as Crosta technique, identifies the principal components that contain spectral information about specific features (e.g. vegetation/mineral) by the analysis of the eigenvector values, as well as the contribution of each of the original bands to the components in relation to the spectral response of the materials of interest ${ }^{(28,30-33)}$. Depending on the magnitude and sign of the eigenvectors loadings, the materials may be represented in bright or dark pixels in the principal components. Loughlin ${ }^{(29)}$ improvised the FPCS technique by applying the PCA over the selected set of bands in which the target material has diagnostic spectral feature instead of the whole bands. The technique is known as Feature based Principal Component Analysis (FPCA) technique or a Modified Crosta technique ${ }^{(34)}$.

Kimberlite is found to be emplaced in several cratons of India such as Dharwar, Bastar, Singhbhum and Bundelkhand Craton ${ }^{(11,12)}$. Eastern Dharwar craton is the largest Kimberlite Provenance of India, with 4 kimberlite Fields viz., (i) the Wajrakarur Kimberlite Feld (WKF), (ii) the Narayanpet Kimberlite Field (NKF)(iii) the Raichur Kimberlite Field (RKF) and (iv) the Tungabhadra Kimberlite Field (TKF) ${ }^{(11,12)}$. The WKF is the largest of them with more than 40 pipes which have been reported by Geological Survey of India as well as private exploration companies so far, and the count is going on increasing based on new discovery. WKF that admistratively fall in Anantapur district of Andhra Pradesh, has potential for discovery of new pipes in the region. In this study, we attempt to utilize the broad band multispectral imagery (Landsat OLI) to assess its efficacy in targeting the weathered kimberlite pipes of Wajrakarur Kimberlite Field (WKF) (Figure 1).

\subsection{Geological setting of the study area}

The Archaean Dharwar Craton of the India is bounded by Bastar Craton towards north east, Proterozoic Eastern Ghats Mobile Belt (EGMB) towards the east, Deccan Volcanic Province in the north west and the Southern Granulite Terrain (SGT) in the south ${ }^{(35)}$ (Figure 1). The Dharwar Craton is made up of granite-green stone belts as well as of tonalite-trondhjemitegranodiorite (TTG) basement gneiss ${ }^{(36)}$. Numerous Paleo-Mesoproterozoic intracratonic sedimentary basins (e.g. Cuddapah basin) unconformably overlie the granite-greenstone terrain in the eastern end margins. Dharwar craton is divisible into two distinct groups called as Eastern Dharwar Craton (EDC) and Western Dharwar Craton (WDC) ${ }^{(37)}$ based on the history of crustal evolution ${ }^{(38,39)}$. A prominent shear zone located along the eastern margin of the Chitradurga greenstone belt, the Chitradurga Boundary Fault (CBF), is widely considered to be the boundary between these blocks ${ }^{(37-40)}$. A North-south trending Closepet Granite pluton of $2510 \mathrm{Ma}$ age intrude the craton ${ }^{(41)}$. Widespread mafic dyke swarms are also observed in 
the area ${ }^{(42)}$. Kimberlite pipes intruding the EDC represent the youngest rocks $(\sim 1100 \mathrm{Ma})^{(42,43)}$. The kimberlite pipes observed in EDC are grouped under Wajrakarur Kimberlite Field (WKF), Narayanapet Kimberlite Field (NKF) and Raichur Kimberlite Field (RKF) ${ }^{(44)}$. The Wajrakarur Kimberlite Field (WKF) is situated in the eastern part of the Eastern Dharwar Craton (EDC) of the South Indian Shield. WKF includes four kimbelite clusters (i) Wajrakarur-Latavaram Cluster, (ii) Kalyandurg Cluster, (iii) Timmasamudram Cluster and (iv) Chigicherla Cluster ${ }^{(8)}$. Each cluster has several pipes along with more than 40 pipes discovered so far from $\mathrm{WKF}^{(45,46)}$, out of which a few are reported to being diamondiferous.

Kimberlite pipe emplacement in the region is highly controlled by regional lineaments ${ }^{(16)}$ and structural dome ${ }^{(8,47)}$. The lineaments and the dykes show two major trends, NW-SE trending Dharwarian lineaments and NE-SW trending regional faults/lineaments. The probability of kimberlite emplacement increases at the intersection of these two set of lineaments ${ }^{(8)}$. Morphologically, kimberlite pipes occur in sloping grounds or topographically depressed areas, some of them showing circular outline $^{(16)}$. The general geology and the spatial distribution of Kimberlite pipes in WKF with the tectonic settings are shown in Figure 1.
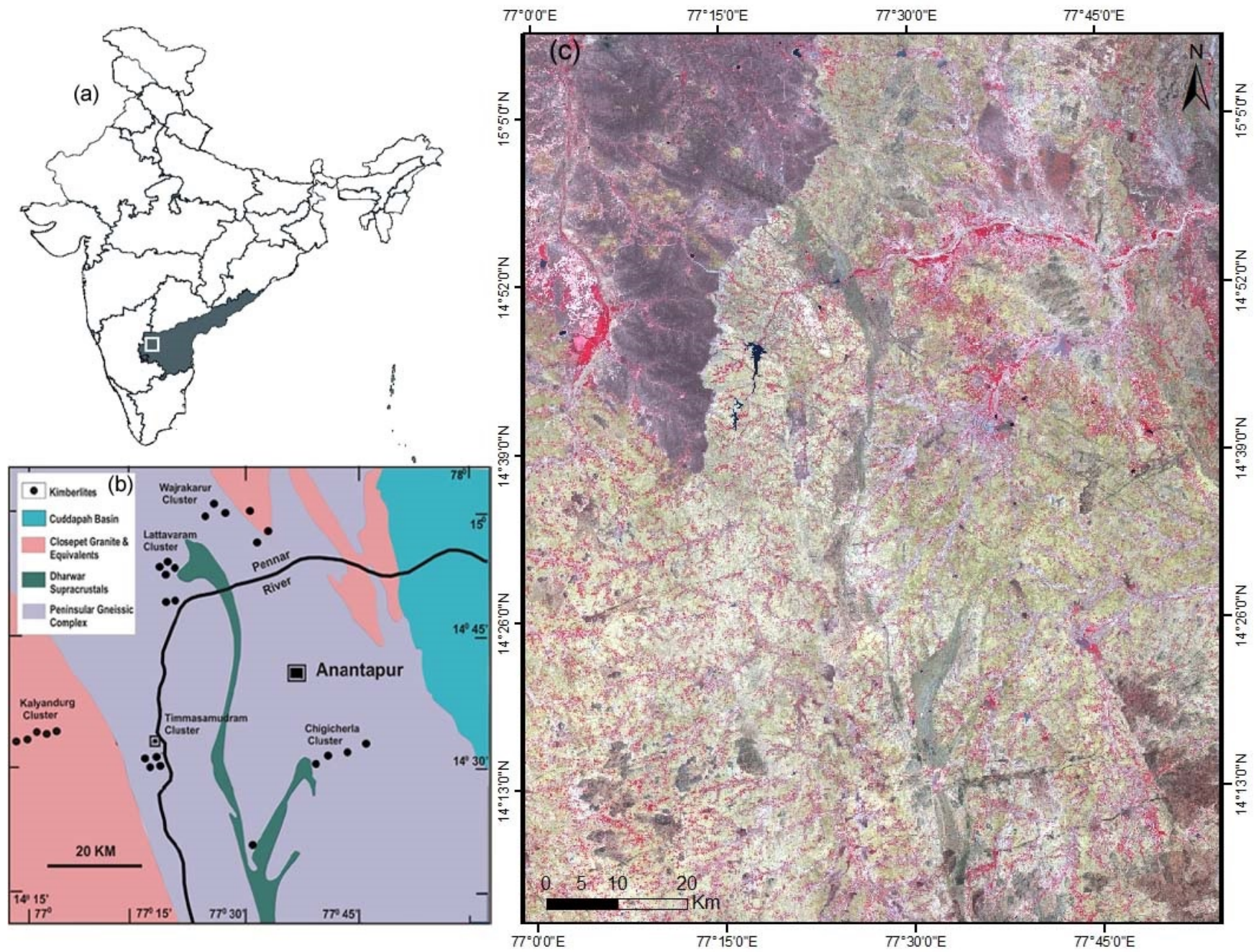

Fig 1. (a)The location mapof the study area; (b) regional geological map of the Wajrakarur Kimberlite field (after Nayak and Kudari, 1999); and (c) Landsat8 OLI standard False Color Composite covering the study area.

\section{Materials and Methods}

The datasets used in the study includes SOI toposheet of the study area of 1:50,000 scale; published geological map, Landsat 8 OLI satellite image and ancillary data about explored kimberlite pipes from published literatures, and limited ground validation. 
The topographical maps and the published Geological maps were georeferenced to geographic coordinate with WGS84 datum and finally stored in the geodatabase.

Cloud free Level 1 Terrain corrected (L1T) Landsat8 OLI multispectral data of the study area LC81440502013103LGN01_WK, acquired on 2013-04-13 was downloaded from Earth Explorer website. Landsat8 has total 11 bands, of which six bands (band 2 to 7 ) are in visible to shortwave infrared region of EMR with a $30 \mathrm{~m}$ spatial resolution. Band 8 is panchromatic band with 15 $\mathrm{m}$ resolution. Band 11 and 12 are thermal bands with $100 \mathrm{~m}$ resolution resampled to $60 \mathrm{~m}$ spatial resolution. Band 1 and band 9 are Coastal aerosol and Cirrus bands respectively, which has $30 \mathrm{~m}$ spatial resolution ${ }^{(48)}$ (Table 1 ).

Table 1. Sensor characteristics of Landsat8 OLI data

\begin{tabular}{llll}
\hline Bands & Wavelength $(\mu \mathrm{m})$ & Spatial Resolution $(\mathrm{m})$ & Date of Acquisition \\
\hline Band 1 - Coastal aerosol & $0.43-0.45$ & 30 \\
Band 2 - Blue & $0.45-0.51$ & 30 \\
Band 3 - Green & $0.53-0.59$ & 30 \\
Band 4 - Red & $0.64-0.67$ & 30 \\
Band 5 - Near Infrared (NIR) & $0.85-0.88$ & 30 \\
Band 6 - SWIR 1 & $1.57-1.65$ & 30 \\
Band 7 - SWIR 2 & $2.11-2.29$ & 30 \\
Band 8 - Panchromatic & $0.50-0.68$ & 15 \\
Band 9 - Cirrus & $1.36-1.38$ & 30 \\
Band 10 - Thermal Infrared (TIRS) 1 & $10.60-11.19$ & $100 *(30)$ & $13 / 04 / 2013$ \\
Band 11 - Thermal Infrared (TIRS) 2 & $11.50-12.51$ & $100 *(30)$ & \\
\hline
\end{tabular}

The Level 1 Terrain corrected (L1T) Landsat 8 data provides the terrain corrected data in calibrated Digital Numbers (DNs). Data in each band (Band 2 to Band 7) were first converted to at-sensor-radiance, which was given as input to FLAASH (Fast Line of sight Atmospheric Analysis of Hypercube) atmospheric correction modelling tool in ENVI. FLAASH incorporates the MODTRAN4 radiation transfer code ${ }^{(48-50)}$ and converts the radiance values to the Top-of-Atmosphere (TOA) reflectance values. The reflectance bands were further used for analysis to target iron oxides, clay/carbonate minerals and also for lineament mapping in the area.

Feature based Principal Component Analysis (FPCA) technique is a modified version of the PCA method developed by Crosta and Moore ${ }^{(28)}$. It allows application of PCA over selected combination of bands that provide crucial information about a particular target object ${ }^{(29)}$. The target was delineated based on the eigenvector loading of the most spectrally significant band over the Principal components ${ }^{(29,30)}$. Field studies as well as literature about kimberlite pipes exposed in the Eastern Dharwar craton and around the globe had revealed that the Kimberlite pipes were marked by presence of red soil mixed with clay or calcrete. Therefore, it was decided to target iron oxide, clay and carbonate minerals as a proxy for locating kimberlite pipes in the study area. Band selection for FPCA was decided based on the spectral signature of the target minerals. From Figure 2, it can be seen that the iron oxide has strong absorption in blue region, whereas it has high reflection in the red region. Similarly, the hydroxyl ion bearing mineral (clay) exhibit diagnostic absorption spectrum around $2.2 \mu \mathrm{m}$ to $2.3 \mu \mathrm{m}$ and depending upon the nature of the clay minerals strong reflection around $1.5 \mu \mathrm{m}$ region. The carbonate minerals exhibit diagnostic absorption around $2.3 \mu \mathrm{m}$. As the spectral resolution of the Landsat OLI image is moderate, the clay and carbonate absorption would have been recorded in the SWIR2 band (Landsat OLI band 7) itself and could not be identified separately and hence mapped together.

In order to target hydroxyl/carbonate minerals, PCA transformations were applied over an image data that contain Landsat 8 OLI bands 2, 5, 6 and 7. In a similar way, PCA transformation were applied over an image that contained bands 2, 4, 5 and 6 to target iron oxide. The Eigen vector loading of each band on the Principal component were noted and the principal component that has the highest loading was considered to map the target. The clay/carbonate minerals or iron oxides could be distinguished by noting the eigenvector loading of corresponding bands having diagnostic spectral characteristics in the PC component by careful examination of correlation matrix. The hydroxyl/carbonate minerals could be better distinguished by a PC image with high or moderate eigenvector loadings for band 7, either in positive or negative sign; and a high or moderate eigenvector loadings of the opposite sign for band 6. If band 7 loadings are positive, then the clay/hydroxyl/carbonate bearing minerals will be highlighted as dark pixels in the PC image, these pixels can be made brighter by negation of the PC ${ }^{(28-34)}$. Similarly, for iron oxide, the magnitude of eigenvector loading of band 2 and 4 in the PCs has to be studied and it should be moderate or strong with opposite signs. 


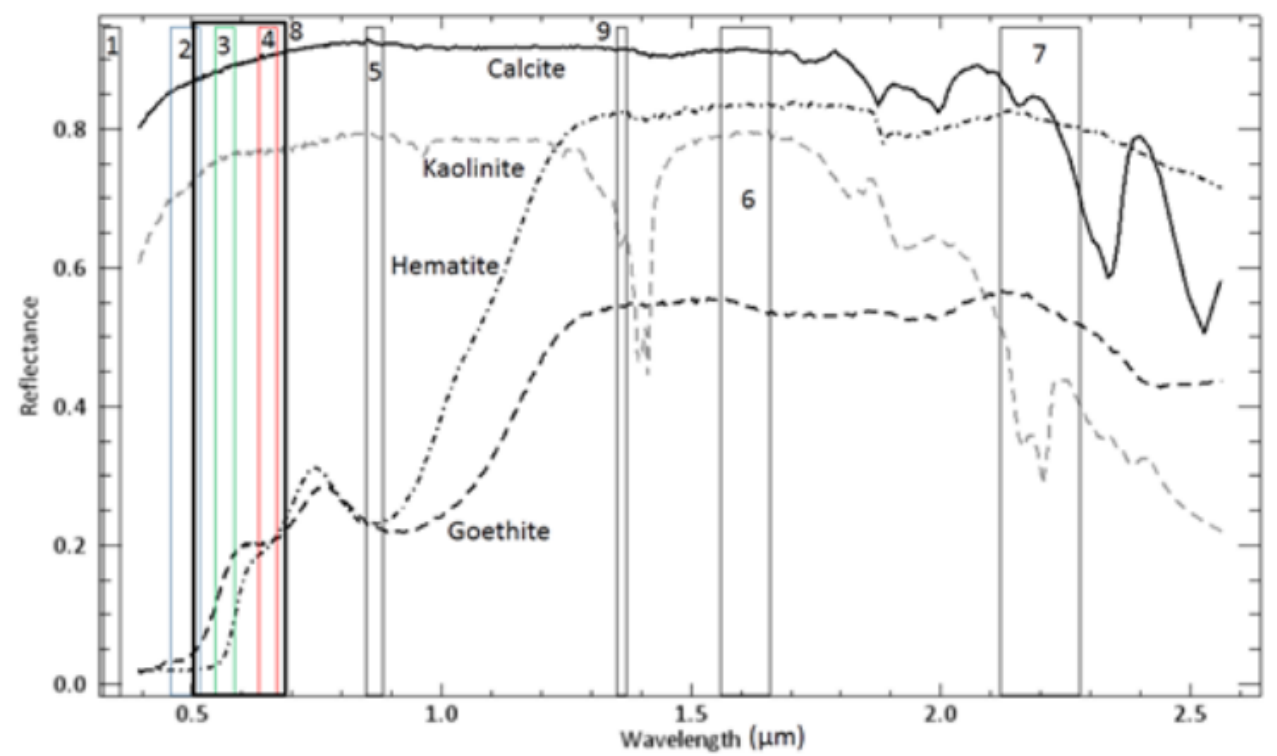

Fig 2. Reflectance spectra of calcite, clay and iron oxides representing the weathered Kimberlite products (source: USGS spectral library). Lands at 8 bands ( 1 to 9) are overlaid over the spectral plot of minerals. The SWIR band 2 (Band 7) does not resolve between clay and carbonate minerals.

The colour composite generated by combining the H/C, F components were useful in highlighting the regions rich in these minerals ${ }^{(34)}$. To create colour composite, a third band was also needed, and hence $\mathrm{H} / \mathrm{C}$ and $\mathrm{F}$ images were added together to produce $\mathrm{F}+\mathrm{H} / \mathrm{C}$ image which highlights the region having both iron oxide and hydroxyl/carbonate minerals. Colour composite was prepared by assigning red colour to $\mathrm{H} / \mathrm{C}$ image, green colour to $\mathrm{F}+\mathrm{H} / \mathrm{C}$ image and blue colour was assigned to $\mathrm{F}$ image ${ }^{(34)}$. Prior to generation of the colour composite image, the H/C, F and H/C +F images were rescaled to 256 grey levels to normalize the values in each image. The resulting colour composite was compared with the locations of kimberlite pipe previously explored by GSI and other agencies. ISODATA ${ }^{(51)}$ unsupervised classification technique was applied over the colour composite to derive the spectral classes representing kimberlite, hereafter referred to as Kimberlite Classes. In order to narrow down the kimberlite class, it was decided to incorporate structural control in emplacement of kimberlite. In the same context, the lineament buffer zone was generated to mark the zone of influence and incorporated while finalizing the kimberlite probable zones. The results were cross verified with kimberlite pipe positions as well as field observations

\section{Results and Discussion}

\subsection{FPCA Analysis to target Kimberlite pipe locations}

FPCA facilitates targeting a particular object by observing the eigenvector loading of the most spectrally significant band over the Principal components ${ }^{(33)}$. Iron oxides and Clay/Carbonate can be distinguished by noting the eigenvector loading of corresponding bands having diagnostic spectral characteristics in the PC component by careful examination of correlation matrix. Iron oxide was targeted by applying FPCA transformations over OLI bands2, 4, 5 and 6 . The eigenvector loading of each band on the Principal component are given in Table 2. Iron oxide shows higher reflectance in red band (band 4) and less reflectance in blue band (band 2). Therefore, the magnitude of eigenvector loading of band 2 and 4 in the PCs were studied. The PC band that have eigenvector loading of these bands in moderate or strong with opposite signs was considered for targeting Iron oxide. Table 2 revealed that the eigenvector loading for the first principle component image (PC1) of bands 2, 4, 5 and 6 has positive values for all corresponding bands. The high positive values represent the albedo component and hence neglected ${ }^{(29)}$. Eigenvector loadings for PC2 and PC 3 are high for Band 5 compared to other bands ( 0.575 and 0.613$)$ and hence the bright pixels in PC2 and PC3 were considered as Vegetation. Eigenvector loading for the PC4 show that band 4 has high negative loading $(-0.862)$, whereas band 2 has moderate loading with opposite sign $(+0.369)$, therefore the iron oxide would be represented as dark pixels. To highlight these pixels as bright pixels, the PC4 was negated and the resulting image corresponds to "Ferric iron 
image" (Figure $3 \mathrm{~A})$.

Table 2. PCA Eigenvector values of Band 2,4,5,6 (Blue, Red, NIR, SWIR1) Landsat 8 data

\begin{tabular}{llllllll}
\hline Eigenvector & Band 2 & Band 4 & Band 5 & Band 6 & Eigen value & Eigenvalue (\%) & Inference \\
\hline PC1 & 0.331 & 0.400 & 0.541 & 0.661 & 229493504 & 98.64 & Aldedo \\
PC2 & 0.470 & -0.065 & 0.575 & -0.670 & 2035563 & 0.87 & Vegetation \\
PC3 & -0.730 & -0.297 & 0.613 & 0.043 & 959521 & 0.41 & Vegetation \\
PC4 & 0.369 & -0.864 & -0.003 & 0.342 & 165700 & 0.07 & Iron Oxide \\
\hline
\end{tabular}

Table 3. PCA Eigenvector values of Band 2,5,6,7 (Blue, NIR, SWIR1, SWIR2) Landsat 8 data

\begin{tabular}{llllllll}
\hline Eigenvector & Band 2 & Band 5 & Band 6 & Band 7 & Eigenvalue & Eigen value (\%) & Inference \\
\hline PC1 & 0.310 & 0.508 & 0.624 & 0.506 & 258722941 & 98.51 & Albedo \\
PC2 & 0.427 & 0.671 & -0.368 & 0.481 & 2841320 & 1.08 & Vegetation \\
PC3 & 0.835 & -0.489 & -0.169 & 0.188 & 942489 & 0.36 & Vegetation \\
PC4 & -0.158 & 0.229 & -0.678 & 0.690 & 141112 & 0.05 & Hydroxyl/Carbonate \\
\hline
\end{tabular}

Clay/Carbonate minerals were targeted by applying FPCA transformations over OLI bands 2, 5, 6 and 7 and the eigenvector loading of each band on the Principal component is given in Table 3. Clay/Carbonate minerals exhibit strong reflection in SWIR band 1 (band 6) and strong absorption in SWIR band 2 (bands 7). Therefore, clay/carbonate minerals can be better distinguished by a PC image with high or moderate eigenvector loadings for band 7, either in positive or negative sign; and a high or moderate eigenvector loadings of the opposite sign for band 6. If band 7 loadings were positive, then the clay/hydroxyl/carbonate bearing minerals would be highlighted as dark pixels in the PC image. These pixels could be highlighted by negation of the PC. It was observed that the eigenvector loadings of band 6 and band 7 in PC4 were high compared to other bands, and in opposite signs $(-0.6679$ and +0.6903 respectively), and highlights hydroxyl/carbonate minerals as dark pixels. Since band 7 has +ve loading, PC4 image was negated to derive Hydroxyl/carbonate minerals as a Bright pixel and represents "Hydroxyl/Carbonate (H/C) image" (Figure 3B). H/C image highlights regions that have both clay rich region as well as carbonate rich region in the study area.

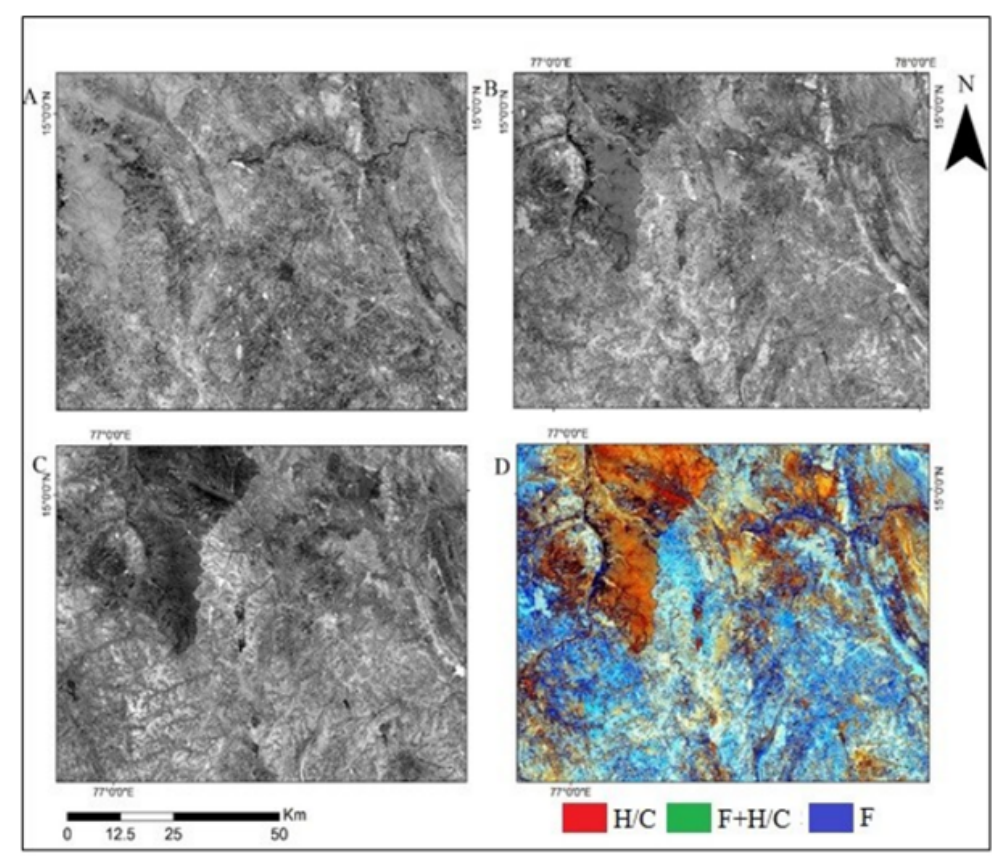

Fig 3. Results of the FPCA applied over Landsat8 OLI image. A) Ferric Ion (F) Image; B) Hydroxyl/Carbonate(H/C)Image; C) F+H/C, Image; D) Colour composite image (R:H/C, G:F+H/C+F, B:F) 
$\mathrm{F}+\mathrm{H} / \mathrm{C}$ image (Figure 3C) highlights area that have higher Iron oxide, hydroxyl bearing or carbonate minerals. The colour composite image prepared by assigning RGB colours to $\mathrm{H} / \mathrm{C}, \mathrm{F}+\mathrm{H} / \mathrm{C}$ and $\mathrm{F}$ image bands respectively (Figure 3D) exhibits various colours ranging from white, dark blue, cyan, red and orange colour depending on the concentration of dominant factor. For example, pixels having white colour indicate region of these pixels that were enriched in both iron oxide and clay/carbonate minerals. Pixels with dark red to orange colour represent areas with higher abundance of clay/carbonate minerals than iron oxide, dark blue pixel represents iron oxide dominant areas, cyan to bluish tone indicate varying amount of iron oxide and clay/carbonates.

While correlating the colour composite image with the geological map and known Kimberlite pipe locations, it was noted that the pixel corresponding to the black soil show orange colour, granites show dark blue colour, whereas the area covering Kimberlite pipes exhibit light blue to cyan colours. From this, it can be inferred that pixels corresponding to Kimberlite pipes have both iron oxide as well as clay/carbonate minerals. Spectrally, iron oxide and hydroxides are dominant than the clay/carbonate minerals ${ }^{(34)}$ and hence the actual concentration of iron oxide might be less than what it appears. However, it was difficult to attribute one single colour to the kimberlite pipe as there was a varying shades of blue, corresponding to varying amount of the carbonate/ clay and iron oxides covering the kimberlite pipe. The observation matches with the field observation also, where the calcrete was seen mixed with red soil and the concentration of iron oxide and clay may vary from place to place.

\subsubsection{ISODATA classification}

In order to further narrow down the regions of possible occurrence of Kimberlite pipe, ISODATA ${ }^{(51)}$ unsupervised classification of the colour composite was carried out. The Isodata classification resulted in generation of 16 classes. It was observed that the known Kimberlite pipes do not fall in one single class; instead they are found to occur in class8, 9, 11and 12. All the above four classes that coincide with the known Kimberlite location were retained to produce a Kimberlite classification map representing the regions with chance of occurrence of Kimberlite pipes(Figure 4). The classification map shows a large area as kimberlite, which was over representation and could be attributed to the false positive identification. The situation might have raised due to lower spatial and spectral resolution of Landsat image as well as occurrence of surface material which has similarity to kimberlite weathering products. In such case, the mapping needs to be refined by taking help of other factors such as structural control or morphology and hence, influence of lineament over the emplacement of kimberlite pipes was considered to narrow down the Kimberlite classification map.

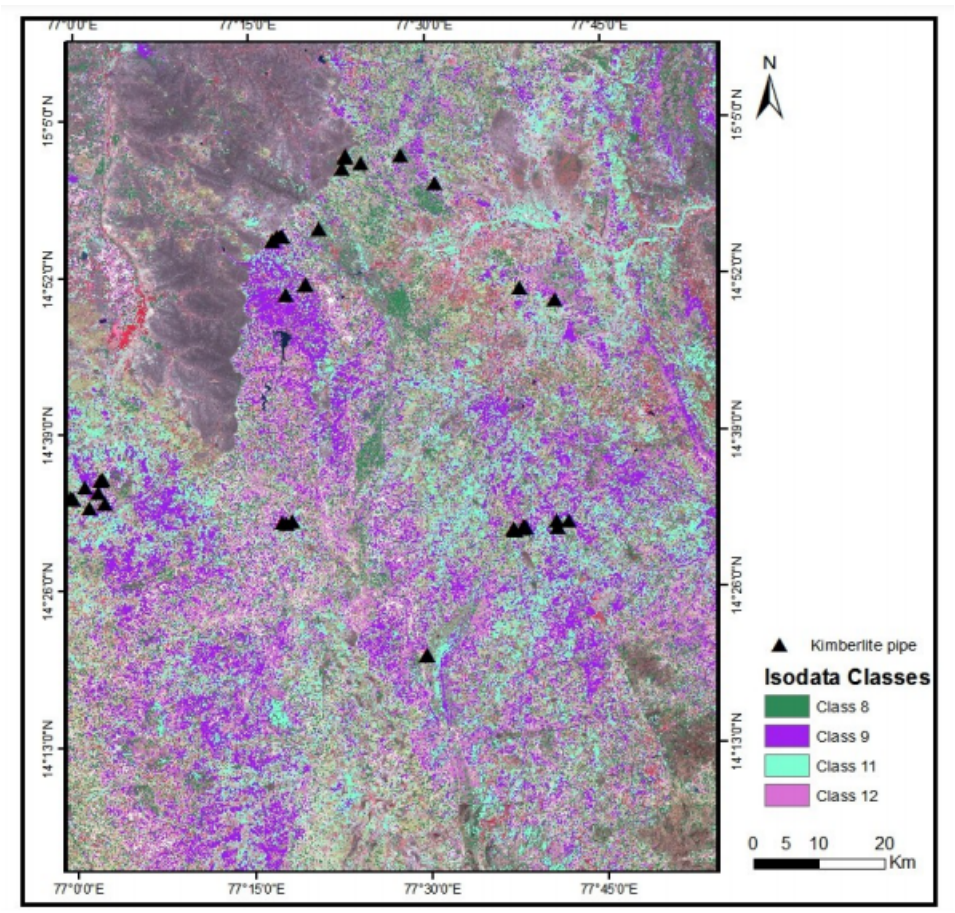

Fig 4. Result of unsupervised classification overlaid over the standard FCC of the study area. Class 8, 9, 11 and 12 represents the Kimberlite classes. Locations of the kimberlite pipes are marked for reference. 


\subsection{Lineaments Mapping}

Lineaments in the study area were generated from Landsat 8 OLI False Colour Composite. Lineaments were interpreted by visual interpretation technique and onscreen digitization was carried out in ArcGIS. Image enhancement techniques such as application of directional filters were applied to highlight the invisible lineaments. To eliminate the cultural lineaments such as roads, railway network etc. the data was compared with Survey of India toposheets and high resolution Google Earth images. Lineament map of Wajrakarur Kimberlite Field is shown in Figure 5. Many of the lineament are marked by intrusion of mafic dykes. Kimberlite pipes in the study area are generally found to be emplaced along regional scale weak zones, particularly intersection of the E-W Lineaments with N-S trending lineaments are more probable locations for the Kimberlite emplacement ${ }^{(17,18)}$. Kimberlite pipes are also observed to fall in between two set of parallel E-W trending lineaments and intersection of N-S lineament.

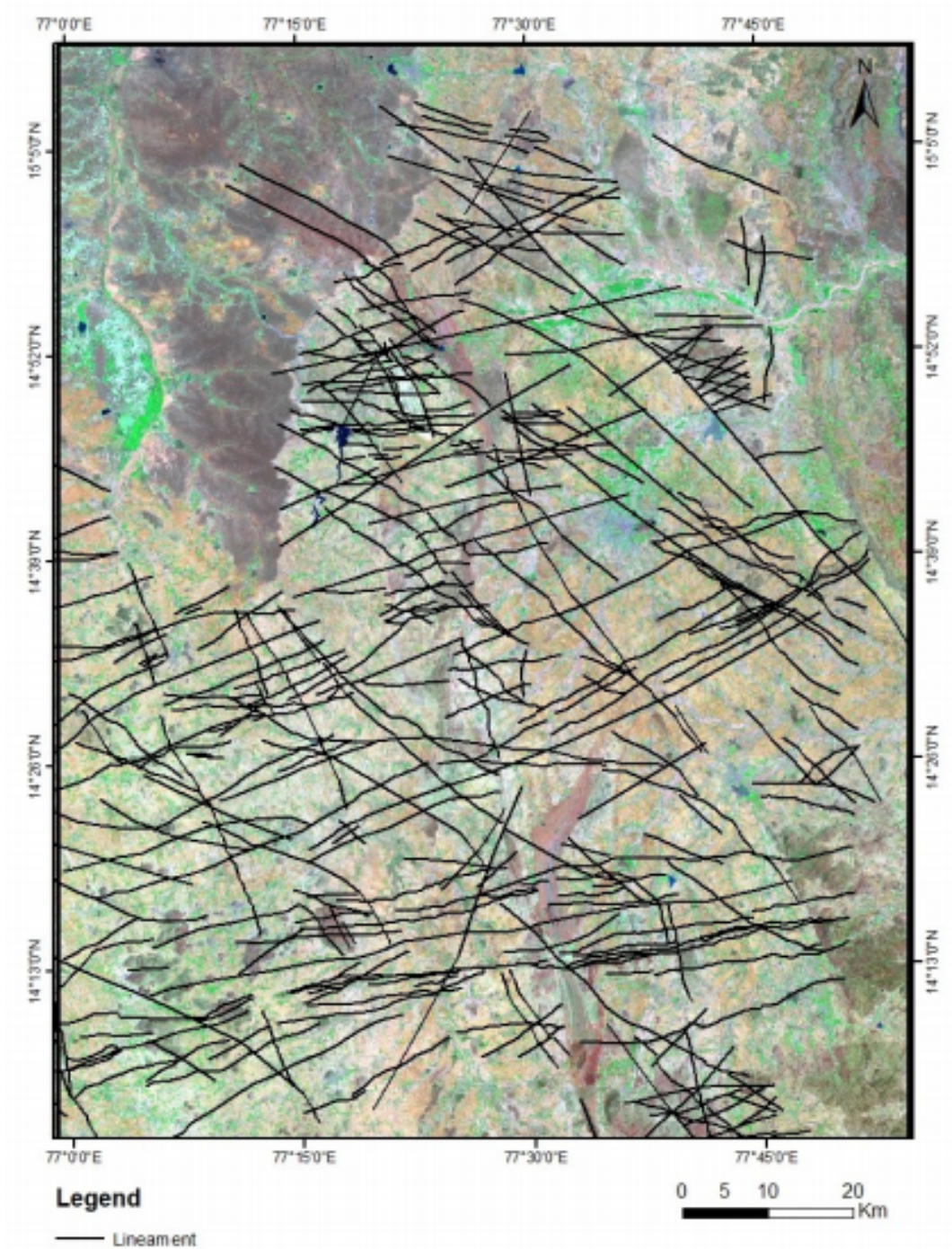

Fig 5. Lineament overlain over the Landsat 8 OLI colour composite image (R:7 G:5 B:4)

\subsection{GIS analysis and field validation}

The present study attempts to locate the probable locations of kimberlite pipes occurrence in the Wajrakarur Kimberlite Field (WKF) using multispectral remote sensing image. Field observation had revealed that fresh kimberlite outcrops were rare and pipes in the study area were of smaller dimension. Since the spatial extent of Landsat 8 OLI is $30 \mathrm{~m}$, the pipes were usually covered 
by a few pixels and hence it was difficult to discern the smaller dimension kimberlite pipes. Most of the kimberlite pipes were deeply weathered and often covered by few meter thick calcrete or transported soil. The calcrete which was developed over the kimberlite couldnot be spectrally resolved from the pedogenic calcrete developed over granitoid/granitic gneiss, thus resulted in false positives. The problem was compounded by the large spatial extent of the pixel which results in the mixed pixel. Based on the analysis of ASTER image of Narayanapeta kimberlite field, Guha et al. ${ }^{(12)}$ concluded that calcrete cannot be detected from a mixed pixel of granite/granodiorite and calcrete with the later making up less than 10 weight percentage of the mixture. Hence results of the spectral based mapping technique to target kimberlite needs to be viewed with caution. Constraining the image analysis results by taking inputs from tectonic and geomorphic setting of kimberlite emplacement might reduce the false positives and enhance the results. ${ }^{(12)}$

Kimberlite emplacement in the study area was found to be structurally controlled, as majority of the kimberlites pipes were found to be in the vicinity of deep-rooted regional scale lineament, particularly where the NE-SW/E-W trending lineament intersects with NW-SE/N-S trending lineaments ${ }^{(8)}$. Hence, the result of image analysis was refined by considering the lineament control over kimberlite emplacement. The zone of influence of the lineament on the kimberlite pipe emplacement was noted by overlaying the pre-explored pipe locations on the lineament map in the GIS environment. Most of the kimberlite pipes, except a few were found to occur at distance of few meters to $1000 \mathrm{~m}$ from the lineament. Accordingly, a buffer zone of about $1000 \mathrm{~m}$ around the lineament was considered to narrow down the Kimberlite emplacement zone.

Four Kimberlite Classes derived from Isodata Classification were merged together to a single class, which was later converted to vector format and stored in GIS geodatabase along with lineament buffer zone. Integration overlay analysis was carried out in ARCGIS to retain the Kimberlite class that occur within the buffer zone of lineaments and were considered as high probabilistic of Kimberlite emplacement zones (Figure 6). The results of GIS analysis were validated by comparing them with the geological map, and field observation.

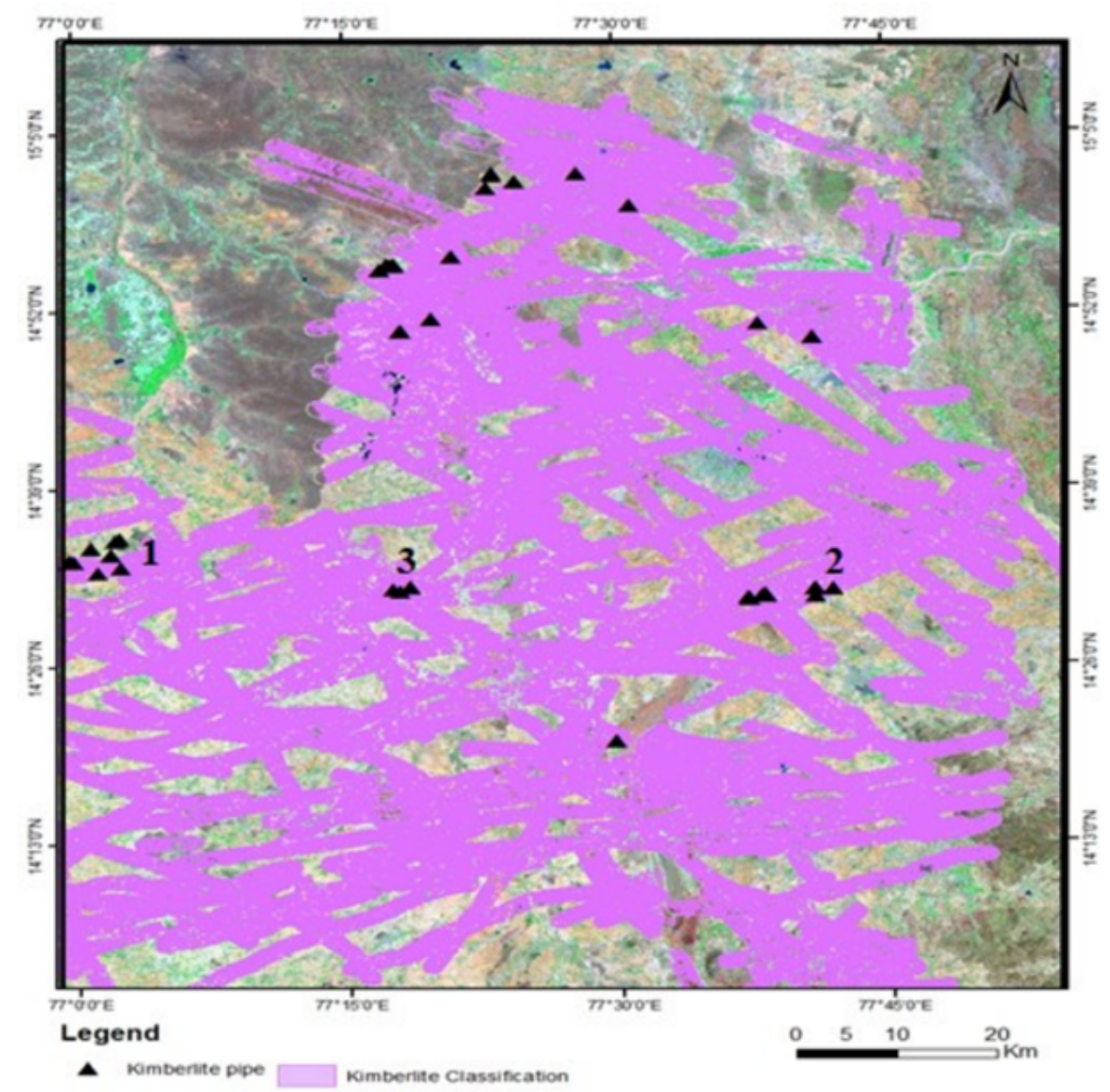

Fig 6. The kimberlite map derived using Isodata classification restricted to the lineament buffer zone. The location of previously explored kimberlite pipes are overlaid over the map. 1,2, and 3 marks the locations of the field photographs shown in Figure 7 
From Figure 6, it was noted that incorporation of the structural control over the kimberlite mapping brought down the kimberlite class area drastically; thus reducing the false positive. Overlaying the known kimberlite pipes over the refined kimberlite classification map, showed that most of the existing kimberlite pipes fall within refined Kimberlite classification. During field validation, previously known kimberlite pipe locations [Figure 7] and six new locations were visited. The preexplored kimberlite pipe locations matched with kimberlite class derived from Landsat OLI and GIS analysis. Of the other six places visited, four locations had development of calcrete cover. Further detailed study such as rock sample analysis, geophysical exploration would be needed to verify the results.
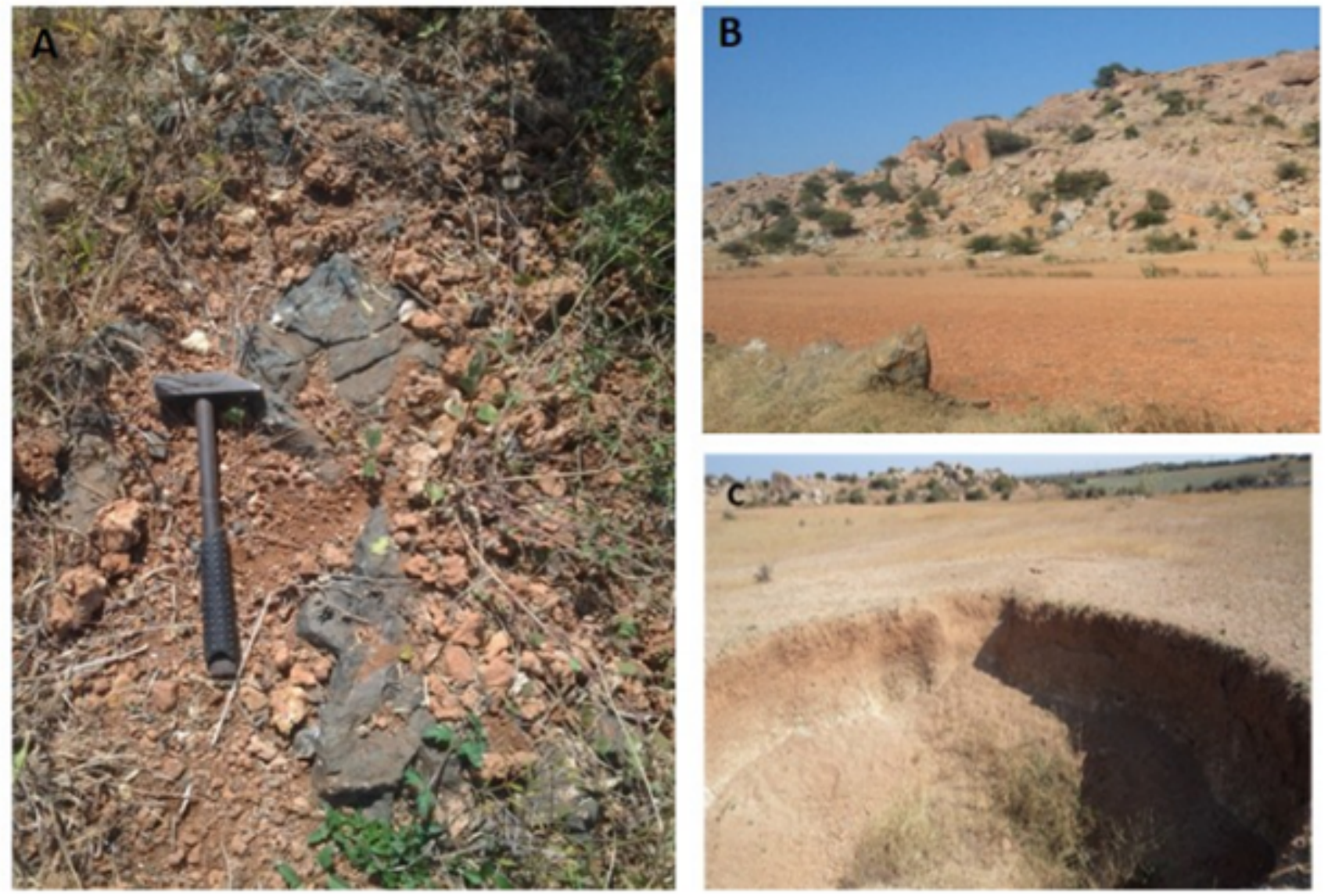

Fig 7. Field Photos A. Kimberlite boulders and Calcrete observed at Kalyandurg (marked as 1in Figure 6) B. Calcrete mixed with red soil in a field observed at Chiggicherla(marked as 2 in Figure 6) C. Clay and calcrete observed in a pit where Kimberlite was dug out at Lattavaram ( marked as 3 in Figure 6)

\section{Conclusion}

This study attest to feasibility of using Landsat 8 OLI data to locate the weathered kimberlite pipe exposed in a semi-arid region. Through FPCA technique, it was possible to locate the iron oxides and the clay or carbonate minerals, the pathfinder minerals for targeting the kimberlite pipe. Though lower spatial and spectral resolution of Landsat data resulted in few false positive signature, constraining with the known kimberlite locations and structural control (lineaments) was observed to enhance its efficiency in mapping of kimberlite. The refined map may be given as input in further GIS analysis which will aid in preparation of Kimberlite prediction map in any given area. 


\section{Acknowledgement}

LRPH acknowledges the University Grants Commission (UGC) and Pondicherry University for providing the fellowship to carry out the PhD work. Authors also acknowledge USGS for allowing free download of Landsat 8 OLI data used in this study. The authors acknowledge the two anonymous reviewers and the editor for their suggestions and critical comments which helped in improving the manuscript.

\section{References}

1) Dawson JB, Kimberlites, Berlin. Kimberlites and their xenoliths Berlin. New York. Springer-Verlag. 1980.

2) Clement CR, Skinner E. A textural-genetic classification of kimberlites. Geological Society of South Africa Transactions. 1985;88:403-409.

3) Mitchell RH. Kimberlites: mineralogy, geochemistry and petrology;vol. 1. New York. Springer US. 1986. Available from: https://doi.org/10.1007/978-14899-0568-0.

4) Fareeduddin, Mitchell RH. Diamonds and Their Source Rocks in Indi. Bangalore. Geological Society of India. 2012.

5) Wagner PA. The Diamond Fields of Southern Africa. Lohannesburg. Transvaal Leader. 1914.

6) Clifford TN. Tectono-metallogenic units and metallogenic provinces of Africa. Earth and Planetary Science Letters. 1966;1(6):421-434. Available from: https://dx.doi.org/10.1016/0012-821x(66)90039-2.

7) Dawson JB. The structural setting of African kimberlite magmatism. In: Clifford TN, Gass IG, editors. African Magmatism and Tectonics. Edinburgh. Oliver \& Boyd. 1970.

8) Nayak SS, Kudari SAD. Discovery of diamond-bearing kimberlites in Kalyandurg area. Current Science. 1999;76(8):1077-1079. Available from: https://www.currentscience.ac.in/Downloads/article_id_076_08_1077_1079_0.pdf.

9) Ramadass G, Himabindu D, Veeraiah B. Morphostructural prognostication of kimberlites in parts of eastern dharwar craton: Inferences from remote sensing and gravity signatures. Journal of the Indian Society of Remote Sensing. 2006;34:111-121. Available from: https://dx.doi.org/10.1007/bf02991816.

10) Jaques AL. Kimberlite and lamproite diamond pipes. AGSO Journal of Australian Geology \& Geophysics. 1998;17(4):153-162.

11) Detailed Information Dossier (DID) on Diamond in India, Geological Survey of India. 2011.

12) Guha A, Ravi S, Rao DA, Kumar KV, Rao END. Issues and Limitations of Broad Band Remote Sensing of Kimberlite-A Case Example from Kimberlites of Dharwar Craton, India. International Journal of Geosciences. 2013;04(02):371-379. Available from: https://dx.doi.org/10.4236/ijg.2013.42035.

13) Kruse FA, Boardman JW. Characterization and mapping of kimberlites and related diatremes using hyperspectral remote sensing. In: and others, editor. 2000 IEEE Aerospace Conference. Proceedings (Cat. No. 00TH8484);vol. 3. IEEE. 2000;p. 299-304. Available from: http://doi.org/10.1109/AERO.2000. 879859.

14) Keeling J, Mauger A, Raven M. Airborne Hyperspectral Survey and Kimberlite Detection in the Terowie District, South Australia. In: Roach IC, editor. Regolith. 2004;p. 166-170. Available from: https://citeseerx.ist.psu.edu/viewdoc/download?doi=10.1.1.556.81\&rep=rep1\&type=pdf.

15) Guha A, Kumar KV, Ravi S, Rao END. Reflectance spectroscopy of kimberlites-in parts of Dharwar Craton, India. Arabian Journal of Geosciences. 2015;8(11):9373-9388. Available from: https://dx.doi.org/10.1007/s12517-015-1850-3.

16) Guha A, Rao DA, Ravi S, Kumar KV, Rao END. Analysis of the potential of Kimberlite rock spectra as spectral end member using samples from Narayanpet Kimberlite Field, Andhra Pradesh. Current science. 2012;103(9):1096-1104. Available from: https://www.currentscience.ac.in/Volumes/103/09/1096.pdf.

17) Guha A, Rani K, Varma CB, Sarwate NK, Sharma N, Mukherjee A, et al. . Identification of Potential Zones For Kimberlite Exploration- An Earth Observation Approach. In: and others, editor. The International Archives of the Photogrammetry, Remote Sensing and Spatial Information Sciences. 2018;p. 239-250. Available from: https://doi.org/10.5194/isprs-archives-XLII-5-239-2018.

18) Prasath HLR, Kusuma KN, Chaitanya S, Guru B. Frequency ratio modelling using geospatial data to predict Kimberlite Clan of rock emplacement zones in Dharwar Craton, India. International Journal of Applied Earth Observation and Geoinformation. 2019;74:191-208. Available from: https: //dx.doi.org/10.1016/j.jag.2018.08.019.

19) Atkinson WJ, Hughes FE, Smith CB. A review of the kimberlitic rocks of Western Australia. In: Komprobst J, editor. Proceedings of the Third International Kimberlite Conference;vol. 1. New York. Elsevier Press. 1984.

20) Muggeridge MT. Pathfinder sampling techniques for locating primary sources of diamond: Recovery of indicator minerals, diamonds and geochemical signatures. Journal of Geochemical Exploration. 1995;53(1-3):183-204. Available from: https://dx.doi.org/10.1016/0375-6742(94)00061-f.

21) Roy A. Calcrete to kimberlite: A prospector's hunt for "kimberlite traits" in calcretes. Journal of the Geological Society of India. 2009;73(3):320-324. Available from: https://doi.org/10.1007/s12594-009-0012-1.

22) Kumar S, Pal SK, Guha A. Very low frequency electromagnetic (VLF-EM) study over Wajrakarur kimberlite Pipe 6 in Eastern Dharwar Craton, India. Journal of Earth System Science. 2020;129(1). Available from: https://dx.doi.org/10.1007/s12040-020-1367-3.

23) Macnae J. Applications of geophysics for the detection and exploration of kimberlites and lamproites. Journal of Geochemical Exploration. 1995;53(13):213-243. Available from: https://dx.doi.org/10.1016/0375-6742(94)00057-i.

24) Power M, Hildes D. Geophysical strategies for kimberlite exploration in northern Canada. Procedings of Exploration 07: Fifth Decennial International Conference on Mineral Exploration. 2007;p. 1025-1031. Available from: http://www.dmec.ca/ex07-dvd/E07/pdfs/89.pdf.

25) Clark RN, Roush TL. Reflectance spectroscopy: Quantitative analysis techniques for remote sensing applications. Journal of Geophysical Research: Solid Earth. 1984;89(B7):6329-6340. Available from: https://dx.doi.org/10.1029/jb089ib07p06329.

26) Kruse FA. Use of airborne imaging spectrometer data to map minerals associated with hydrothermally altered rocks in the northern grapevine mountains, Nevada, and California. Remote Sensing of Environment. 1988;24(1):31-51. Available from: https://dx.doi.org/10.1016/0034-4257(88)90004-1.

27) Sabins FF. Remote sensing for mineral exploration. Ore Geology Reviews. 1999;14(3-4):157-183. Available from: https://dx.doi.org/10.1016/s01691368(99)00007-4.

28) Crosta PA, Moore JM. Geological mapping using Landsat Thematic Mapper imagery in Almeria Province, south-east Spain. International Journal of Remote Sensing. 1989;10(3):505-514. Available from: https://dx.doi.org/10.1080/01431168908903888.

29) Loughlin WP. Principal Component Analysis for Alteration Mapping. Photogrammetric Engineering \& Remote Sensing. 1991;57(9):1163-1169. Available from: https://www.asprs.org/wp-content/uploads/pers/1991journal/sep/1991_sep_1163-1169.pdf.

30) Ranjbar H, Honarmand M, Moezifar Z. Application of the Crosta technique for porphyry copper alteration mapping, using ETM+ data in the southern part of the Iranian volcanic sedimentary belt. Journal of Asian Earth Sciences. 2004;24(2):237-243. Available from: https://dx.doi.org/10.1016/j.jseaes. 
2003.11.001.

31) Sultan M, Arvidson RA, Sturchio NC, Guinness EA. Lithologic mapping in arid regions with Landsat thematic mapper data: Meatiq dome, Egypt. Geological Society of America Bulletin. 1987;99(6):748-748. Available from: https://dx.doi.org/10.1130/0016-7606(1987)99<748:Imiarw>2.0.co;2.

32) Kaufmann H. Mineral exploration along the Aqaba-Levantstructure by use of TM data; concepts, processing, and results. International Journal of Remote Sensing. 1988;9(10-11):1639-1658. Available from: https://doi.org/10.1080/01431168808954966.

33) Bennett SA, Atkinson WW, Kruse FA. Use of Thematic Mapper Imagery to Identify Mineralization in the Santa Teresa District, Sonora, Mexico. International Geology Review. 1993;35(11):1009-1029. Available from: https://dx.doi.org/10.1080/00206819309465572.

34) Tangestani MH, Moore F. Iron oxide and hydroxyl enhancement using the Crosta Method: a case study from the Zagros Belt, Fars Province, Iran. International Journal of Applied Earth Observation and Geoinformation. 2000;2(2):140-146. Available from: https://dx.doi.org/10.1016/s0303-2434(00) 85007-2.

35) Ramakrishnan M, Vaidyanadhan R. Geology of India;vol. I. Bangalore. Geological Society of India. 2008.

36) Naqvi SM, Rogers JJW. Precambrian Geology of India. In: and others, editor. Oxford Monographs on Geology and Geophysics. Oxford University Press. 1987. Available from: https://doi.org/10.1002/gj.3350230412.

37) Friend CRL, Nutman AP. SHRIMP U-Pb geochronology of the Closepet granite and peninsular gneisses. Journal of Geological Society of India. 1991;38(4):357-368. Available from: http://www.geosocindia.org/index.php/jgsi/article/view/66805.

38) Jayananda M, Chardon D, Jj P, Capdevila R. 2.61 Ga potassic granites and crustal reworking in the western Dharwar craton, southern India: tectonic, geochronologic and tectonic constraints. Precambrian Research. 2006;150:1-26. Available from: https://doi.org/10.1016/j.precamres.2006.05.004.

39) Chadwick B, Vasudev VN, Ahmed N. The Sandur schist belt and its adjacent plutonic rocks: implications for late Archaean crustal evolution in Karnataka. Journal of the Geological Society of India. 1996;7:37-57.

40) Ramakrishnan M, Vaidyanadhan R. Geology of India;vol. 2. and others, editor;Geological Society of India. 2010.

41) Moyen JF, Martin H, Jayananda M, Auvray B. Late Archaean granites: a typology based on the Dharwar Craton (India). Precambrian Research. 2003;127(13):103-123. Available from: https://dx.doi.org/10.1016/s0301-9268(03)00183-9.

42) Kumar A, Kumari VMP, Dayal AM, Murthy DSN, Gopalan K. RbSr ages of Proterozoic kimberlites of India: evidence for contemporaneous emplacement. Precambrian Research. 1993;62(3):227-237. Available from: https://dx.doi.org/10.1016/0301-9268(93)90023-u.

43) Rao NVC, Wu FY, Mitchell RH, Li QL, Lehmann B. Mesoproterozoic U-Pb ages, trace element and Sr-Nd isotopic composition of perovskite from kimberlites of the Eastern Dharwar craton, southern India: Distinct mantle sources and a widespread 1.1Ga tectonomagmatic event. Chemical Geology. 2013;353:48-64. Available from: https://dx.doi.org/10.1016/j.chemgeo.2012.04.023.

44) Paul DK, Nayak SS, Pant NC. Indian kimberlites and related rocks: petrology and geochemistry. Journal of the Geological Society of India. 2006;67(3):328355. Available from: http://www.geosocindia.org/index.php/jgsi/article/view/81919.

45) Shaikh AM, Patel SC, Ravi S, Behera D, Pruseth KL. Mineralogy of the TK1 and TK4 'kimberlites' in the Timmasamudram cluster, Wajrakarur Kimberlite Field, India: Implications for lamproite magmatism in a field of kimberlites and ultramafic lamprophyres. Chemical Geology. 2017;455:208-230. Available from: https://dx.doi.org/10.1016/j.chemgeo.2016.10.030.

46) Neelakantam S. Exploration for diamonds in southern India. In: and others, editor. Geological Survey of India Special Publication;vol. 58. 2001;p. 521-555.

47) Phani PRC. Area Selection for Diamond Exploration Based on Geological and Morphostructural Set-Up : Examples from Wajrakarur Kimberlite Field. India Journal of Advanced Chemical Sciences. 2015;1(3):102-106. Available from: https://www.jacsdirectory.com/journal-of-advanced-chemical-sciences/ admin/issues/20150526042757_1-3-08\%20JACS2015043.pdf.

48) Landsat8 Data Users Handbook. 2019. Available from: Availablefrom:https://prd-wret.s3.us-west-2.amazonaws.com/assets/palladium/production/ atoms/files/LSDS-1574_L8_Data_Users_Handbook-v5.0.pdf.

49) Kruse FA, Lefkoff AB, Boardman JW, Heidebrecht KB, Shapiro AT, Barloon PJ, et al. The spectral image processing system (SIPS)-interactive visualization and analysis of imaging spectrometer data. Remote Sensing of Environment. 1993;44(2-3):145-163. Available from: https://dx.doi.org/10.1016/00344257(93)90013-n.

50) Matthew MW, Adler-Golden SM, Berk A, Richtsmeier SC, Levine RY, Bernstein LS, et al. Status of atmospheric correction using a MODTRAN4based algorithm. InAlgorithms for multispectral, hyperspectral, and ultraspectral imagery VI. In: and others, editor. International Society for Optics and Photonics;vol. 4049. 2000;p. 199-207.

51) Tou JT, Gonzalez RC. Pattern Recognition Principles. Reading, Massachusetts. Addison-Wesley Publishing Company. 1974. 